\title{
Impact of water quality on Chronic Kidney Disease of unknown etiology (CKDu) in Thunukkai Division in Mullaitivu District, Sri Lanka
}

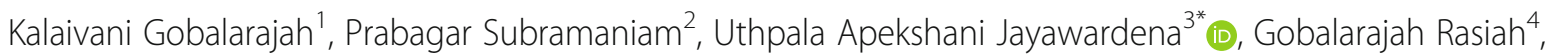
Sittampalam Rajendra $a^{5}$ and Jasotha Prabagar ${ }^{6}$

\begin{abstract}
Background: Increase in the number of cases in Chronic Kidney Disease of Unknown etiology (CKDu) in Sri Lanka has become a health issue of national concern. Even though, Northern Province is not identified as a high-risk province, there is an increasing trend of CKDu after the end of civil war in the Northern Province.

Methods: The present study was conducted in Thunukkai Division in Mullaitivu District to investigate the socio demographic and clinical pattern of CKDu patients and to evaluate the quality of their water sources. The samples were selected by using stratified purposive random sampling method which represented 29\% of total CKDu patients in Thunukkai Division. Pretested structured questionnaire was administered to collect the data from the CKDu patients. The association between serum creatinine excreted by CKDu patients and the water quality parameters were determined by using linear regression model.

Results: Among the patients, $80 \%$ were male with over $68 \%$ falling in the age range of $50-70$. Majority (90\%) were involved in agriculture related occupation. Smoking and alcohol consumption were detected as common habits among $40 \%$ of the patients. Secondarily developed, hypertension (60\%) and diabetes (34\%) were reported as common diseases in the area. Dug wells served as the commonest source of drinking water in the area ( $90 \%$ households) together with few tube wells. Physicochemistry of more than $50 \%$ of the water samples revealed higher electric conductivity, salinity, total dissolved solids, total hardness and Na levels compared to drinking water standards in Sri Lanka.

Conclusions: Serum creatinine levels of the CKDu patients were significantly and negatively correlated with phosphate while positively correlated with total dissolved solids (TDS) and arsenic content of the drinking water. Geospatial mapping of TDS and arsenic in drinking water with the occurrence of higher serum creatinine levels confirmed the same trend. Thus, the total dissolved solids and arsenic in drinking water may have positive correlation with the occurrence of CKDu in Thunukkai region in the Mullaitivu District of Sri Lanka.
\end{abstract}

Keywords: Chronic kidney disease of unknown etiology, Water quality parameters, Serum creatinine

\footnotetext{
*Correspondence: uajay@ou.ac.lk

${ }^{3}$ Department of Zoology, Faculty of Natural Sciences, The Open University of Sri Lanka, Colombo, Sri Lanka

Full list of author information is available at the end of the article
}

(c) The Author(s). 2020 Open Access This article is licensed under a Creative Commons Attribution 4.0 International License, which permits use, sharing, adaptation, distribution and reproduction in any medium or format, as long as you give appropriate credit to the original author(s) and the source, provide a link to the Creative Commons licence, and indicate if changes were made. The images or other third party material in this article are included in the article's Creative Commons licence, unless indicated otherwise in a credit line to the material. If material is not included in the article's Creative Commons licence and your intended use is not permitted by statutory regulation or exceeds the permitted use, you will need to obtain permission directly from the copyright holder. To view a copy of this licence, visit http://creativecommons.org/licenses/by/4.0/ The Creative Commons Public Domain Dedication waiver (http://creativecommons.org/publicdomain/zero/1.0/) applies to the data made available in this article, unless otherwise stated in a credit line to the data. 


\section{Background}

Chronic Kidney Disease of unknown etiology (CKDu) is the occurrence of Chronic Kidney Disease (CKD) without a known underlying cause [1]. Since its first report in mid-90's cases of CKDu have increased tremendously in North Central Province of Sri Lanka [2]. It is estimated that thousands of Sri Lankan people are affected by $\mathrm{CKDu}$, mostly poor families living in remote areas. However, the number of CKDu patients and causes of the disease are unknown. Unfortunately, the research studies conducted to date were unable to provide exact cause/s of CKDu. A common conclusion is that the $\mathrm{CKDu}$ is caused by multiple factors involving environmental and social impacts [3].

There are several etiologies, proposed by the researchers of $\mathrm{CKDu}$, including demographic factors of the affected community [4], quality of their drinking water including hardness [5], agrochemical and heavy metal contaminations [5, 6] fluoride level [7], the genetic makeup of vulnerable populations [8], etc. Demographic factors include the socioeconomic characters of a population such as age, sex, occupation etc. Several studies conducted in the North Central Province revealed that the main livelihood of $\mathrm{CKDu}$ affected population is farming and the age of the patients ranged between 30 and 60 with higher prevalence among elderly males over 50 years of age $[2,5,9]$. Low water consumption during farming activities and dehydration due to the exposure to direct sunlight may have led to renal failure [5]. Disease aggravating habits such as alcohol consumption, betel chewing and smoking have also been investigated in relation to patient demography [5]. A common genetic variant close to SLC13A3 is reported to be related to $\mathrm{CKDu}$ [10]. This has been identified as the most sensitive gene marker to predict the renal disease of type 2 diabetes mellitus. Furthermore, genes such as IGFBP1, KIM1, GCLC and GSTM1 are proposed to be used in combination for early determination of CKDu [11].

Correlation between high groundwater hardness and the occurrence of $\mathrm{CKDu}$ have been frequently reported $[8,9,12,13]$. According to World Health Organization (WHO) hard water is mainly caused by the presence of calcium, magnesium, strontium, and iron together with carbonate, bicarbonate, sulphate and chloride anions. Furthermore, possible correlation between fluoride $(F)$ in drinking water and the prevalence of CKDu was suggested in various instances [12-14]. According to WHO (2011), Sri Lanka is one of the tropical countries in the world with higher fluoride content in water resources, reaching the upper limit value of $0.6 \mathrm{mg} / \mathrm{L}$ [15]. In most of the CKDu endemic areas F content exceeds the upper limit value [16]. Maximum permissible contaminant level of Arsenic (As) is $10 \mu \mathrm{g} / \mathrm{L}$ though As contamination in the disease endemic regions exceeded the upper limit
[17]. However, Balasooriya et al., [9] and Nanayakkara et al., [8] found insignificant levels of As and other trace elements in drinking water of CKDu endemic areas of Sri Lanka.

Algal toxins have also been considered as a suspect of the CKDu [18]. According to WHO, eighteen different types of cyanobacteria are capable of producing toxins under favourable conditions. Among them, fifteen toxic producing cyanobactria have been identified in Sri Lankan reservoirs and canals. These toxins are identified as hepatotoxic, dermatotoxic, neurotoxic and nephrotoxic compounds [18].

$\mathrm{CKDu}$ has direct impact on patients' lives including their livelihood activities. As the disease advances, patients become too ill to continue their employment, affecting the economic conditions and wellbeing of the entire family.

Current data on CKDu distribution show the occurrence of the disease in North Central, North Western, Southern, Eastern and Uva Provinces. Even though, Northern Province is not identified as a high-risk province, $\mathrm{CKDu}$ is developing at an alarming rate after the end of civil war in Northern part of this country. This may be the result of increased use of agrochemicals, residuals of explosives and newly emerging industries with unplanned effluent disposal leading to aquatic pollution in natural reservoirs. Northern Province comprises of five districts; Jaffna, Killinochchi, Mullaitivu, Vavuniya and Mannar. Among these Mullaitivu and Vavuniya have been considered "at risk" for the occurrence of $\mathrm{CKDu}$ with 09 other districts from North Central, Central and Uva provinces $[19,20]$ (Fig. 1). And Northern Province appear to have higher CKD prevalence than Central or Southern Provinces [20]. In the present study, Thunukkai of Mullaitivu District was selected as its prevalence of CKDu has not been studied much. Most of the people in Thunukkai are farmers, who carried out paddy farming throughout the year. Majority in Thunukkai Divisional secretariat use shallow dug wells and reservoirs for their daily consumption without any treatment of water. Thunukkai Divisional Secretariat has many reservoirs. Some GN ("Grama Niladhari"-Public Service Officer) divisions are named according to the name of reservoirs such as Anichakulam, Thenniyankulam, Kodaikadiyakulam etc.

Objectives of this study were to analyze the socio demographic and clinical pattern of CKDu patients in Thunukkai Division, and to determine the water quality parameters, such as cadmium (Cd), arsenic (As), nitrate, phosphate, fluoride, hardness, total dissolved solids (TDS), $\mathrm{pH}$, sodium ( $\mathrm{Na}$ ), potassium $(\mathrm{K})$ and electric conductivity of the drinking water in the wells and to assess correlations between water quality parameters and the serum creatinine levels of the CKDu patients. 


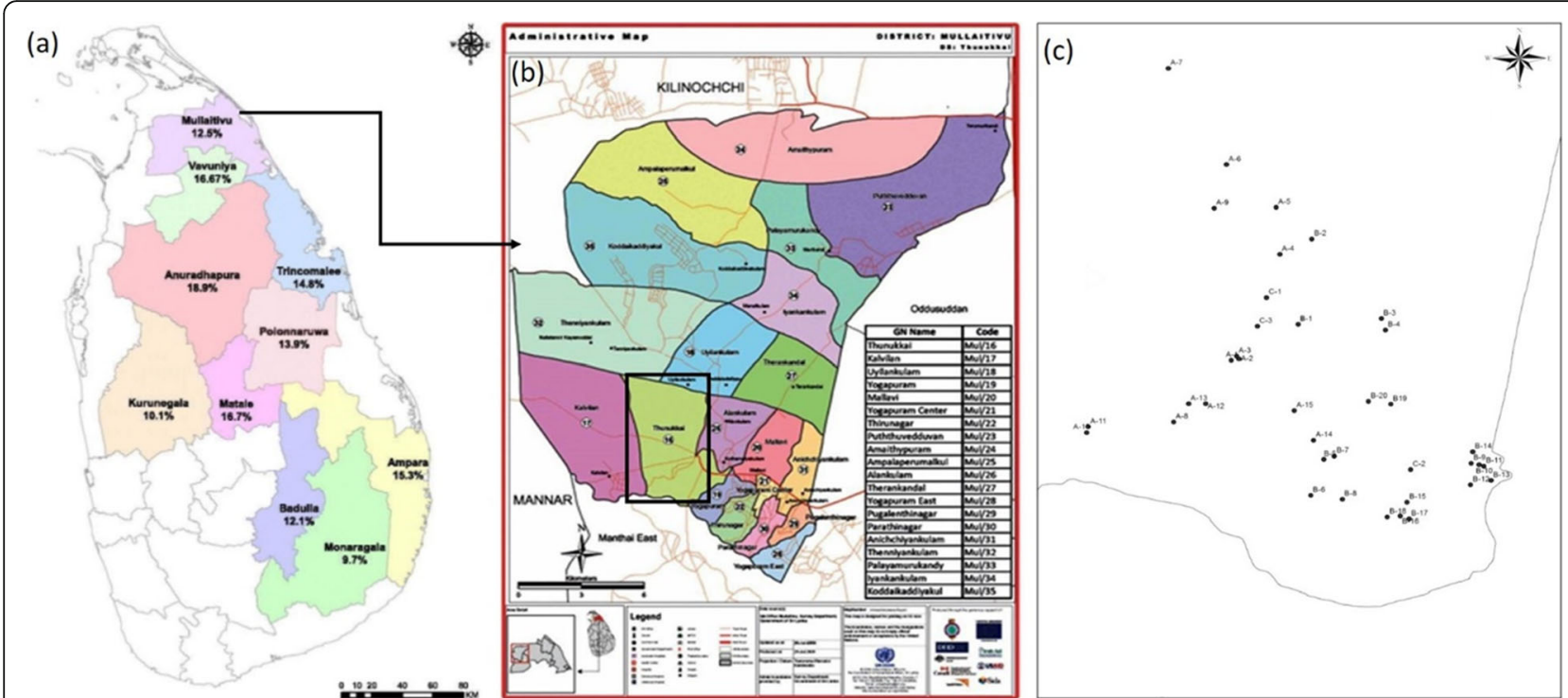

Fig. 1 Thunukkai Divisional secretariat of the Mullaitivu District showing the distribution of drinking water sources (sampling points, A1-A15, B1B20) of the patient households and control samples from C1-C3. \{a CKD prevalence rates across the most affected districts in Sri Lanka [19], b Administrative map of the Mullaitivu District (Sri Lanka Surveys Department, Maps and Geoinformations, https://www.survey.gov.lk) c Sampling points in Thunukkai DS (Drawn with ArcGIS 10.1, https://www.arcgis.com/index.html)\}

\section{Methods}

Ethical clearance was obtained from the Ethics Review Committee, Faculty of Medicine, University of Jaffna. Data regarding CKDu patients were gathered during the period of January 2018 to July 2018 from respective Regional Director of Health Service in Northern Province. In Mullaitivu district, 631 cases of both $\mathrm{CKD}$, including $\mathrm{CKDu}$ were identified in 3 Medical Office of Health $(\mathrm{MOH})$ which are Thunukkai (120 cases), Manthai East (86 cases) and Sampathnuwara (425 cases). Thunukkai division was selected for the present study as it is a scarcely studied area, affected by the civil war.

In Thunukkai Division 120 patients, out of the total population of 10,172 were identified as $\mathrm{CKD} / \mathrm{CKDu}$ patients by $\mathrm{MOH}$ office Mallavi. The water samples were collected by using stratified purposive random sampling method which represented $29 \%$ of total CKDu patients in Thunukkai Division. Sample size (n) was estimated using the equation, $\mathrm{n}=\mathrm{Z}^{2} \mathrm{p}(1-\mathrm{p}) / \mathrm{e}^{2}$, where $\mathrm{Z}=$ confidence level at $95 \%$ (i.e. 1.96), $p=$ estimated prevalence of the area $(120 / 10,172=0.0118)$ and $\mathrm{e}^{2}=$ margin of error. Even though, the sample size $n=18$ was statistically sufficient 35 patients were randomly sampled to cover all the CKDu positive villages of the area.

Sociodemographic data were collected through an interviewer administered questionnaire, developed for the study and filled during the visit to patient's houses (Supplementary file). Data include age, gender, occupation of the patient, clinical signs and symptoms of CKDu (serum creatinine level) and potential habits for the disease progression (smoking and alcohol consumption).

As CKDu patients were distributed in $65 \%$ of total villages in Thunukkai Division water samples were collected in these villages. A total of 38 water samples; 35 samples from CKDu affected areas (Fig. 1, A1-A15, B1-B20) and 3 control samples (Fig. 1, C1-C3) were collected in August 2018. The three control samples were collected from places in Thunukkai central, Yokapuram west and Ugilankulam, where there were no records of CKDu patients.

Water samples were collected during the dry season. Before collecting water, the water column was thoroughly stirred with the collecting bucket. If the water surface has floating scum or algae, those were skimmed before collecting the samples. Water was collected over the depth of $10 \mathrm{~cm}$ below the water surface. In the case of tube wells, pumps were used to take samples of water. Water samples were collected in cleaned plastic bottles which were then refrigerated at $4{ }^{\circ} \mathrm{C}$ until assaying. Physicochemical parameters such as, turbidity, colour, odour, total dissolved solids, alkalinity, salinity, electrical conductivity, $\mathrm{NO}_{3}{ }^{-}, \mathrm{PO}_{4}{ }^{3-}, \mathrm{SO}_{4}{ }^{2-}, \mathrm{F}^{-}$, total hardness, $\mathrm{Ca}^{2+}, \mathrm{Mg}^{2+}$ and $\mathrm{Cl}^{-}$ of the water samples were measured within a week.

Physicochemical properties of the water samples were determined with standard instruments, following the standard procedures. Onsite measurements were obtained with portable meters for $\mathrm{pH}$ (Jenway Phm6, UK), turbidity, electrical conductivity and salinity (Senso direct, con110, USA). TDS was measured gravimetrically with $\mathrm{HCl}$ acid. Alkalinity and total hardness were 
measured using sulfuric acid based and EDTA based complexometric titration methods, respectively. Fluoride $\left(\mathrm{F}^{-}\right)$was measured with SPANDS Spectrophotometric method. $\mathrm{NO}_{3}{ }^{-}, \mathrm{PO}_{4}{ }^{3-}, \mathrm{SO}_{4}{ }^{2-}$ ions were determined by COD multiparameter photometer (HI83399, UK). These analyses were carried out in the Department of Chemistry, University of Jaffna and As and Cd concentrations were measured in Industrial Technological Institute in Colombo using graphite furnace atomic absorption spectrophotometry (GFAAS) with a precision of 0.001 .

By using Geographic information system (GIS) software (ArcGIS 10.1) mapping was conducted for nitrate, phosphate, total hardness, total dissolved solid, fluoride and Arsenic content in water.

Physicochemical parameters of the test samples were compared with those of the control samples and the Sri Lankan standards for potable water. To assess the correlation between water quality parameters and serum creatinine levels of the CKDu patients, linear regression, model was used. Through this analysis, relationships between the target variable (dependent variable) and a set of independent variables (covariates) were quantified. The regression equation estimates a coefficient for each variable. The goal of regression analysis is to generate the line that best fits the observations. However, the best fitted line for the data leaves the least amount of unexplained variation, such as the dispersion of observed points around the line. The following formula describes the linear relationship between dependent and independent variables.

$$
\begin{aligned}
\mathrm{Y}= & \beta 0+\beta 1 \mathrm{a}+\beta 2 \mathrm{~b}+\beta 3 \mathrm{c}+\beta 4 \mathrm{~d}+\beta 5 \mathrm{e}+\beta 6 \mathrm{f} \\
& + \text { error }
\end{aligned}
$$

Where, dependent variable $(\mathrm{Y})$ is the serum creatinine levels of the CKDu patient. Independent variables; anitrate, b-fluoride, c- phosphate, d- Total Dissolved Solid, e- Total hardness, f- Arsenic content in water. Intercept $\beta 0$ - is a constant that defines where the linear trend line intercepts the Y-axis. Coefficient $\beta 1, \beta 2, \beta 3$, $\beta 4, \beta 5$ and $\beta 6$; constants that represent the rate of change in the dependent variable as a function of changes in the independent variable. It is the slope of the linear line. Error, represents the unexplained variation in the target variable. It is treated as a random variable that picks up all the variation in $\mathrm{Y}$ that is not explained by X.

\section{Results}

\section{Demography of the CKDu patients}

Ages of $\mathrm{CKDu}$ patients in Thunukkai Division ranged between 30 and 80 years. Among the studied patients 24 were in the $50-70$ years range, comprising $63 \%$ of the total sample (Table 1). CKDu was more prevalent among males
Table 1 Demographic data and baseline characteristics of the CKDu patients in Thunukkai, Mullaitivu District, Sri Lanka

\begin{tabular}{ll}
\hline Data & Number of patients (\%) \\
\hline Age distribution & $4(11.42 \%)$ \\
$30-40$ & $5(14.28 \%)$ \\
$41-50$ & $12(34.28 \%)$ \\
$51-60$ & $12(34.28 \%)$ \\
$61-70$ & $2(5.71 \%)$ \\
$71-80$ & \\
Sex & $28(80 \%)$ \\
Male & $07(20 \%)$ \\
Female & \\
Occupation & $31(90 \%)$ \\
Agriculture related & $02(5 \%)$ \\
Other & $02(5 \%)$ \\
No occupation & \\
Impact of other habits & $09(25.71 \%)$ \\
Smoking & $07(20 \%)$ \\
Alcohol consumption & $07(20 \%)$ \\
Both- smoking \& alcohol & \\
Disease history & $15(42.82 \%)$ \\
Hypertension & $06(17.14 \%)$ \\
Diabetes & $06(17.14 \%)$ \\
Both hypertension \& diabetes &
\end{tabular}

as the male to female ratio was 4:1. Among them $90 \%$ were engaged in agriculture related occupation while the rest were laborers, drivers, or unemployed people.

According to the data obtained from the questionnaire, more than $20 \%$ of the patients either smoked or consumed alcohol while another $20 \%$ did both.

Clinical data of the selected patients showed existence of other non-communicable diseases such as hypertension (43\%) and diabetes (17\%) with $17 \%$ suffering from both the diseases. The disease history of the patients revealed that they were diagnosed with hypertension and diabetics secondarily, only after they developed CKDu. Furthermore, a spotty pigmentation which was similar to arsenic related keratosis was observed in the palms of three male patients of the study group.

\section{Physicochemical characters of the drinking water}

Dug wells and tube wells serve as the major sources of drinking water in the study area. Thus, drinking water samples from $31 \mathrm{dug}$ wells and 4 tube wells were collected and analysed for the physicochemical parameters. The results of the analyses are given in the Table 2 . Among the parameters salinity, TDS and total hardness showed highest deviations with the corresponding values of more than $50 \%$ samples exceeding the relevant values 
Table 2 Physicochemical properties of the water samples collected from Thunukkai, Mullaitivu District, Sri Lanka

\begin{tabular}{|c|c|c|c|c|c|c|}
\hline \multirow[t]{2}{*}{ Water quality parameter } & \multirow{2}{*}{$\begin{array}{l}\text { Control (Mean } \pm \\
S^{\mathrm{a}}{ }^{\mathrm{a}} \text { ) }\end{array}$} & \multicolumn{3}{|l|}{ Samples } & \multirow{2}{*}{$\begin{array}{l}\text { SLS } \\
614 \\
(2013)\end{array}$} & \multirow{2}{*}{$\begin{array}{l}\% \text { of } \\
\text { water } \\
\text { sample } \\
\text { exceeding } \\
\text { SLS value }\end{array}$} \\
\hline & & Max & Min & Mean $( \pm \mathrm{SD})$ & & \\
\hline Turbidity (NTU') & $0.38 \pm 0.09$ & 26.5 & 0.3 & $2.3 \pm 4.41$ & 2 & 28.8 \\
\hline $\mathrm{pH}$ & $8.0 \pm 0.0$ & 9.1 & 7.4 & $8.2 \pm 0.4$ & $6.5-8.5$ & 17.1 \\
\hline Electric conductivity ( $\mu \mathrm{S} / \mathrm{cm})$ & $935.67 \pm 238.7$ & 6900 & 330 & $1413.31 \pm 1275.4$ & 750 & 17.1 \\
\hline Salinity (g/L) & $0.416 \pm 0.13$ & 3.36 & 0.13 & $0.69 \pm 0.70$ & 0.5 & 50 \\
\hline $\operatorname{TDS}^{d}(\mathrm{mg} / \mathrm{L})$ & $418 \pm 0$ & 3750 & 136.3 & $687 \pm 681$ & 400 & 63.16 \\
\hline Nitrate (mg/L) & $51.66 \pm 31.50$ & 295 & 0 & $28.13 \pm 53.31$ & 50 & 15.17 \\
\hline Fluoride (mg/L) & $0.37 \pm 0.24$ & 22.3 & 0.1 & $1.73 \pm 4.10$ & 1 & 39.5 \\
\hline Phosphate(mg/L) & $3.1 \pm 2.12$ & 4.84 & 0.06 & $0.84 \pm 0.64$ & 2 & 10.6 \\
\hline Total hardness(mg/L) & $340.2 \pm 76.1$ & 683.2 & 39.84 & $295.76 \pm 147.52$ & 250 & 65.4 \\
\hline Magnesium(mg/L) & $29.28 \pm 5.89$ & 68.13 & 0 & $30.19 \pm 1.87$ & 50 & 18.42 \\
\hline Calcium(mg/L) & $86.36 \pm 22.98$ & 193.22 & 3.98 & $64.074 \pm 43.20$ & 100 & 21.05 \\
\hline Sodium(mg/L) & $7.2 \pm 5.43$ & 41.6 & 0.1 & $13.52 \pm 11.46$ & 200 & 0 \\
\hline Potassium(mg/L) & $4.8 \pm 4.16$ & 9.6 & 1.3 & $3.75 \pm 2.00$ & 10 & 0 \\
\hline Sulphate(mg/L) & $13.3 \pm 7.63$ & 160 & 0 & $37.10 \pm 31.35$ & 250 & 0 \\
\hline Alkalinity(mg/L) & $6.37 \pm 1.26$ & 31.87 & 2.46 & $7.2496 \pm 5.41$ & 200 & 0 \\
\hline Chloride(mg/L) & $184.96 \pm 139.9$ & 2066.53 & 6.95 & $367.27 \pm 514.75$ & 250 & 31.42 \\
\hline Arsenic (lowest detected value) (mg/L) & Less than $0.0001 \pm 0$ & 0.03 & Less than 0.0001 & $0.0054 \pm 0.0051$ & 0.01 & 23.7 \\
\hline Cadmium ( $\mu \mathrm{g} / \mathrm{L})$ & Not detected & \multicolumn{3}{|c|}{ Not detected } & 0.003 & 0 \\
\hline
\end{tabular}

${ }^{\mathrm{a} S t a n d r a d}$ deviation, ${ }^{\mathrm{b}}$ Sri Lanka Standards, ${ }^{\mathrm{c}}$ NTU- Nephelometric Turbidity Units, ${ }^{\mathrm{d}}$ TDS-Total dissolved solids

of the Sri Lankan standards, SLS 614:2013 for drinking water (Salinity ranged between $0.13-3.66 \mathrm{~g} / \mathrm{L}$ with an average of $0.69 \mathrm{~g} / \mathrm{L}$ (standard error of mean, $(\mathrm{SEM})=$ 0.12 ), with $50 \%$ of the samples exceeding the standard value of $0.5 \mathrm{~g} / \mathrm{L}$. Similarly, in $63 \%$ of the samples, TDS content exceeded the standard $(400 \mathrm{mg} / \mathrm{L})$ with an average value of $687 \mathrm{mg} / \mathrm{L}(\mathrm{SEM}=115)$ and reaching a maximum of $3570 \mathrm{mg} / \mathrm{L}$. Total hardness of the samples ranged between $39.84-683.26 \mathrm{mg} / \mathrm{L} \quad(\mathrm{SEM}=24.9)$ with $65 \%$ of the samples exceeding the standard $(250 \mathrm{mg} / \mathrm{L})$.

Among other parameters, turbidity, fluoride, chloride, calcium and arsenic contents showed higher deviations from the SLS 614:2013, with more than $20 \%$ samples exceeding the respective limits. Mean turbidity of the drinking water samples was $2.3 \mathrm{NTU}$ (Nephelometric Turbidity Unit) $(\mathrm{SEM}=0.74)$ with a range of $0.3-26.5 \mathrm{NTU}$, all exceeding the mean turbidity of control samples. Ten water samples (29\%) exceeded the standard turbidity level (2NTUSLS 614:2013).

Fluoride content averaged $1.73 \mathrm{mg} / \mathrm{L}(0.1-22.3 \mathrm{mg} /$ L) $(\mathrm{SEM}=0.69)$, with $39 \%$ samples exceeding the standard of $1 \mathrm{mg} / \mathrm{L}$. Similarly, chloride content of $31 \%$ of the water samples exceeded the standard value of $250 \mathrm{mg} / \mathrm{L}$ with an average of $367.27 \mathrm{mg} / \mathrm{L} \mathrm{(6.95-}$ $2066.53 \mathrm{mg} / \mathrm{L}) \quad(\mathrm{SEM}=87.0)$. Calcium averaged 64.07 $\mathrm{mg} / \mathrm{L}(3.98-193.22 \mathrm{mg} / \mathrm{L})(\mathrm{SEM}=7.3)$ with $21 \%$ of the samples having higher values than the standard value $(100 \mathrm{mg} / \mathrm{L})$ for calcium in drinking water. Even though, arsenic detected only in nine samples, the concentration exceeded the standard value $(0.01 \mathrm{mg} /$ L) reaching as high as $0.03 \mathrm{mg} / \mathrm{L}$ in some water samples.

Water quality parameters such as $\mathrm{pH}$, electric conductivity, nitrate, phosphate and magnesium contents showed no substantial deviations, with only $10 \%$ of the samples exceeding the SLS 614:2013. pH of the water samples was 8.2 on the average $(\mathrm{SEM}=0.1)$, ranging between 7.4-9.1. Only six samples had a $\mathrm{pH}$ of more than 8.5 whereas no water sample had $\mathrm{pH}$ below 6.5. The mean value of electrical conductivity was $1416.31 \mu \mathrm{S} / \mathrm{cm} \quad(\mathrm{SEM}=216)$, with the values ranging from 330 to $6690 \mu \mathrm{S} / \mathrm{cm}$. $17 \%$ of the samples exceeded the standard $(750 \mu \mathrm{S} / \mathrm{cm})$. Nitrate content of the samples averaged $28.13 \mathrm{mg} / \mathrm{L},(\mathrm{SEM}=9.01)$, with values ranging from 0 to $295 \mathrm{mg} / \mathrm{L}$. Only $15 \%$ of the water samples contained higher nitrate levels than the standard value, $50 \mathrm{mg} / \mathrm{L}$. The mean phosphate content was $0.84 \mathrm{mg} / \mathrm{L}$ $(0.06-4.8 \mathrm{mg} / \mathrm{L})(\mathrm{SEM}=0.11)$ with $10 \%$ of the samples exceeding the desirable level. Magnesium content had a mean value of $30.19 \mathrm{mg} / \mathrm{L}$ with $18 \%$ of samples exceeding the standard value. 
All the other physicochemical parameters including, $\mathrm{Na}, \mathrm{K}$, sulphate contents and had lower levels compared to their respective Sri Lankan standards. Cadmium was not detected in any of the water samples collected from the sampling area.

According to the data gathered through the questionnaire, the serum creatinine levels of CKDu patients of Thunukkai ranged between $1.31-5.32 \mathrm{mg} / \mathrm{dL}$, with an average of $1.91 \pm 0.84 \quad(\mathrm{SEM}=0.14) \quad \mathrm{mg} / \mathrm{dL}$. Serum creatinine of the control samples had an average, of $0.7 \pm 0.05 \mathrm{mg} / \mathrm{dL} \quad(\mathrm{SEM}=0.03)$, as illustrated in Fig. 2, showing a significantly low value $(\mathrm{t}=8.24, p=0.0001)$.

\section{Correlation between water quality parameters and CKDu patients}

The effect of physicochemical characters of water on the occurrence of CKDu was evaluated by applying the linear regression model, where serum creatinine concentration was treated as the response variable while water quality parameters (nitrate, fluoride, phosphate, etc.) were treated as the explanatory variables. Results are given in the Table 3 below.

$R^{2}$ value of 0.5109 suggests, that six explanatory variables; fluoride, phosphate, TDS, total hardness and arsenic, together account for about $51.09 \%$ of variation in the serum creatinine concentration of the CKDu patients. Among these physicochemical parameters, TDS and As contents showed significantly positive correlation $(p<0.05)$ with the creatinine levels while phosphate
Table 3 Regression analysis between serum creatinine of CKDu patient and explanatory variables, phosphate, TDS and Arsenic contents in water from Thunukkai, Mullaitivu District, Sri Lanka

\begin{tabular}{lllll}
\hline Explanatory variables & Coefficient & St. Error & T value & $\boldsymbol{P}$ value \\
\hline (Intercept) & $1.660 \mathrm{e}^{+00}$ & $1.767 \mathrm{e}^{-01}$ & 9.394 & $5.63 \mathrm{e}-11^{* * *}$ \\
$\mathrm{PO4}^{3-}$ & $2.113 \mathrm{e}^{-01}$ & $1.009 \mathrm{e}^{-01}$ & -2.095 & $0.04377^{*}$ \\
$\mathrm{TDS}$ & $2.829 \mathrm{e}^{-04}$ & $1.592 \mathrm{e}^{-04}$ & 1.777 & 0.0845 \\
As & $1.065 \mathrm{e}^{+02}$ & $2.135 \mathrm{e}^{+01}$ & 4.986 & $1.79 \mathrm{e}-055^{* * *}$ \\
\hline$R^{2}=0.5109,{ }^{*} P<0.05$ and ${ }^{* * *} P<0.01$ & & &
\end{tabular}

content showed significantly negative correlation $(p<$ 0.001, Fig. 3). On the other hand, nitrate content in the drinking water showed no influence on serum creatinine of the CKDu patients in Thunukkai.

The measured total hardness, TDS, nitrate, fluoride, phosphate and arsenic contents in the drinking water of the study area are illustrated in Figs. 4 and 5. Analysis of the spatial distribution data of the patients indicated that seven sampling points have creatinine levels over $2 \mathrm{mg} /$ $\mathrm{dL}$ in the order of, $\mathrm{A} 12>\mathrm{A} 9>\mathrm{A} 4>\mathrm{A} 1>\mathrm{A} 13>\mathrm{B} 13>\mathrm{A} 2$. When these locations were overlapped on the GIS mapping distinct interrelations were identified in TDS, As and phosphate with the creatinine levels (Fig. 4), agreeing with the trend observed in the regression analysis. Higher serum creatinine levels, over $2.5 \mathrm{mg} / \mathrm{dl}$ appeared to be linked with higher total dissolved solids content $650.9-1516 \mathrm{mg} / \mathrm{L}$ (Fig. 4a) and higher arsenic content $1.6-29.7 \mu \mathrm{g} / \mathrm{L}$ (WHO limit of As is $10 \mu \mathrm{g} / \mathrm{L}$ )

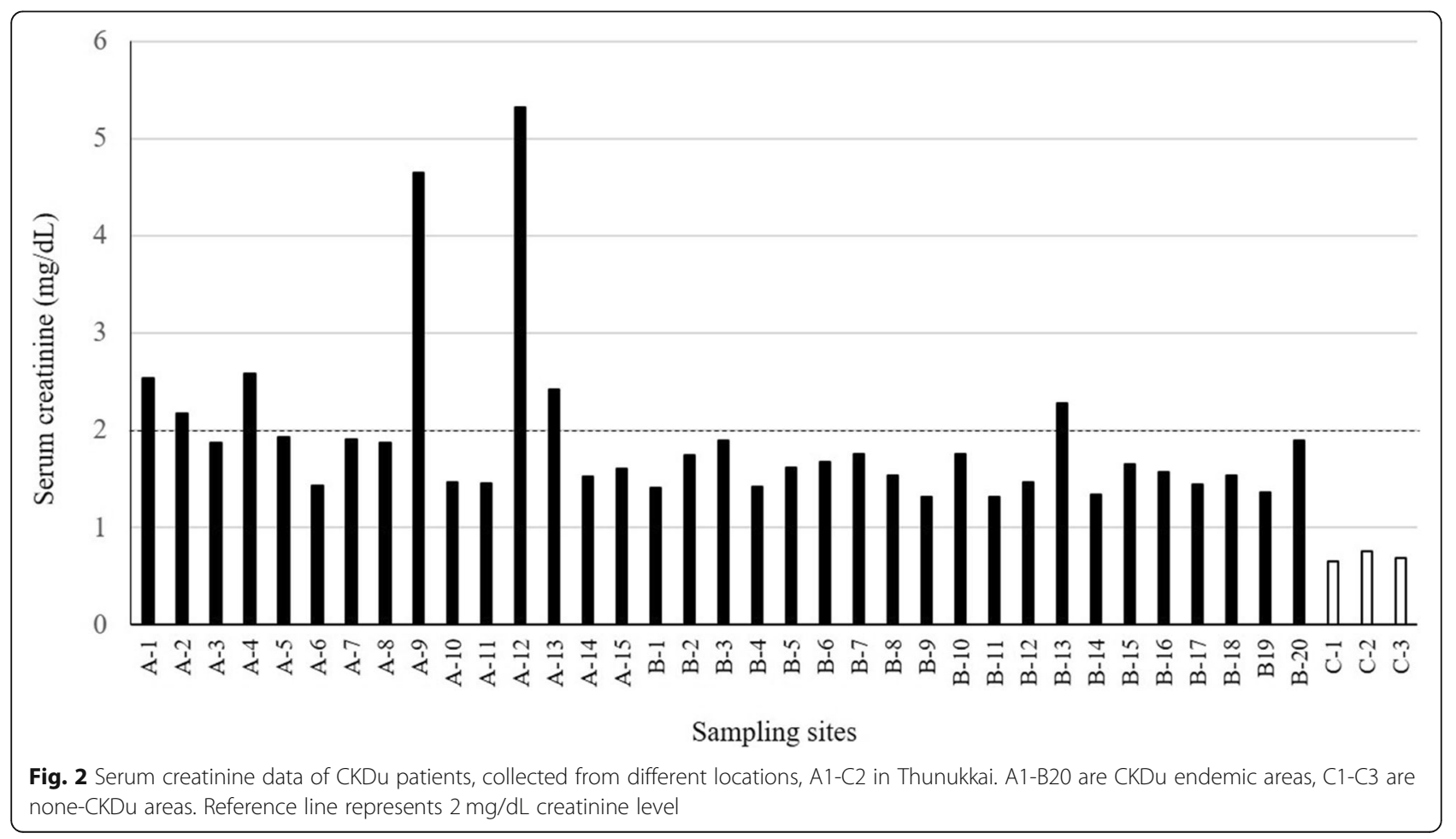



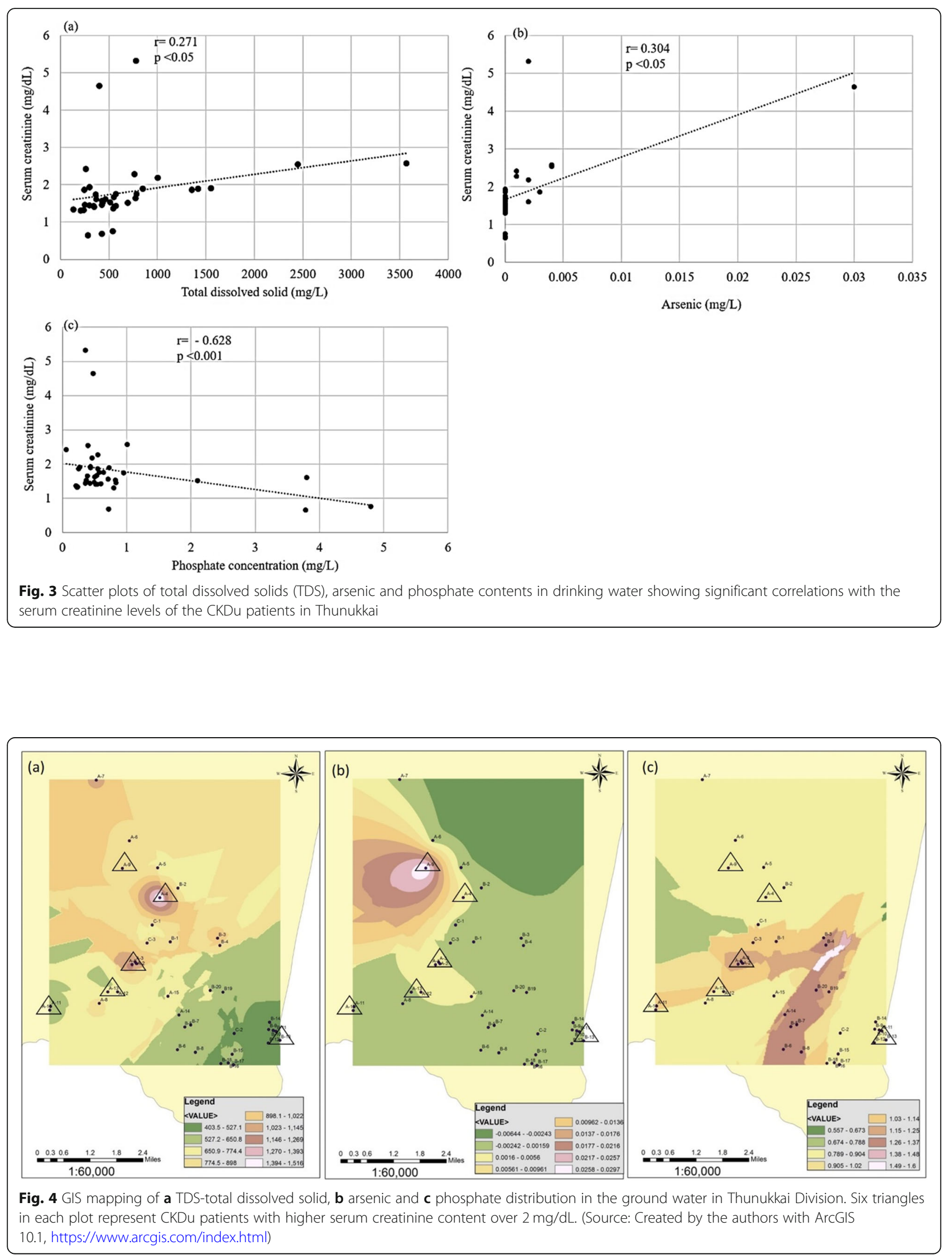

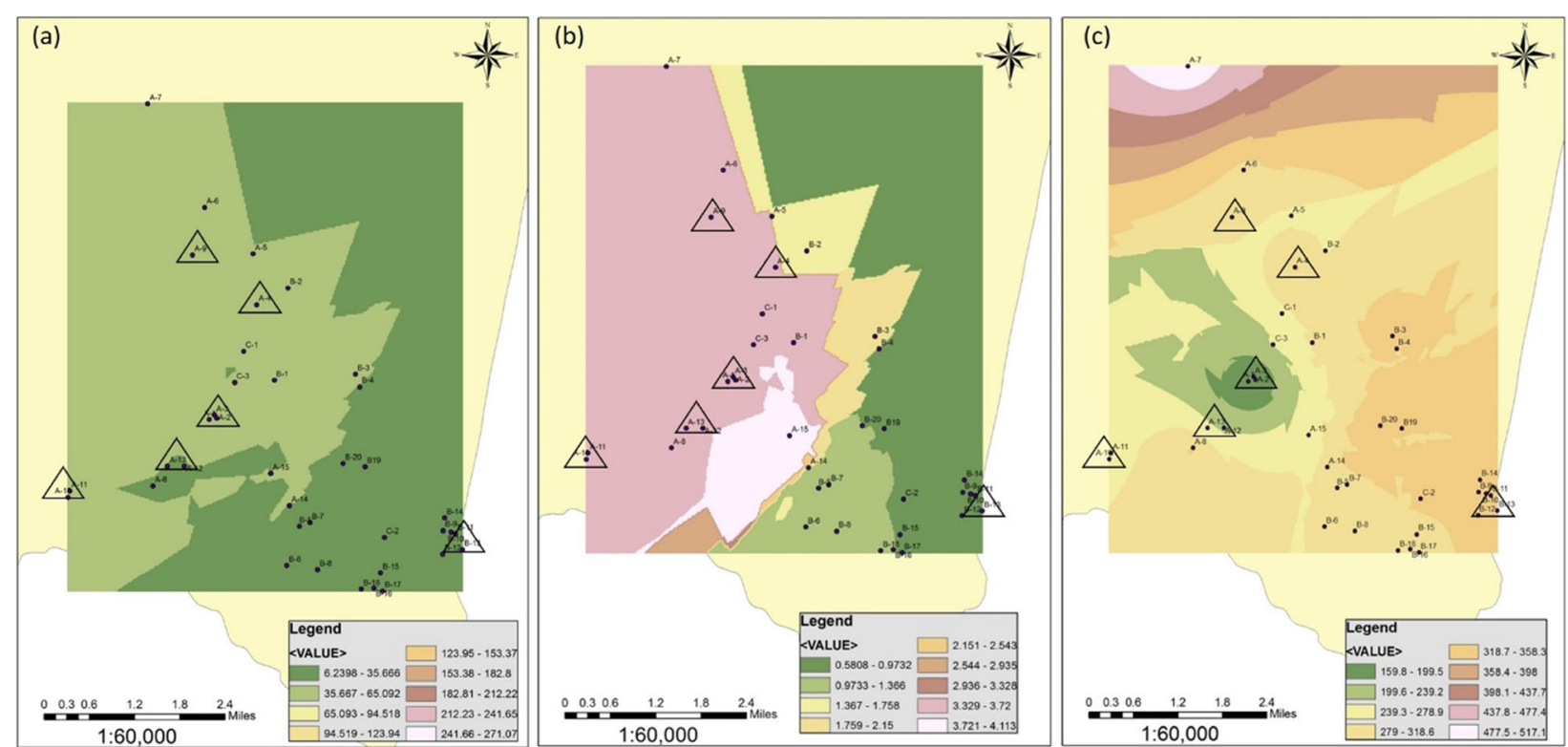

Fig. 5 GIS mapping of a Nitrate, $\mathbf{b}$ fluoride and c total hardness content in the ground water in Thunukkai Division. Six triangles in each plot represent CKDu patients with higher serum creatinine content over $2 \mathrm{mg} / \mathrm{dL}$. (Source: Created by the authors with ArcGIS 10.1, https://www.arcgis.com/index.html)

(Fig. 4b) and low phosphate content, 0.789-0.904 mg/L (Fig. 4c). The spatial distribution of nitrate, fluoride and total hardness contents showed no direct influence on serum creatinine levels in the study samples (Fig. 5a, b \& c).

\section{Discussion}

The present study revealed that the male farmers, aged between 50 and 70 in Thunukkai Division of Mullaitivu developed higher risk of CKDu. Smoking and alcohol consumption may enhance the vulnerability towards the disease. The patients have developed hypertension and diabetes as secondary illnesses after developing the $\mathrm{CKDu}$. Drinking water quality of the area was not at the desirable level, particularly with high ionic content leading to high salinity, dissolved solids and hardness levels. Secondarily, turbidity, fluoride, chloride, and magnesium levels reported disturbingly higher values compared to SL standards. As predicted by the regression model, fluoride, phosphate, TDS, total hardness and arsenic levels together accounted for considerable variation in the serum creatinine of the studied patients. This trend was further validated by the association of geospatial distribution of TDS, arsenic and phosphates with the occurrence of higher serum creatinine levels of the study samples.

Demographic data of the study comply with many other studies conducted in CKDu issue in Sri Lanka. Sex distribution of the presents study, i.e. 4:1, (Male: Female) was consistent with Wanigasuriya et.al [21]., Noble et.al
[22]., Ranasinghe et al. [2], and Balasooriya et al. [9] which reported male preponderance. However, the age distribution was not compatible with Wanigasuriya et.al., [21]) and Noble et.al., [22] who reported as the majority of patients were in the 40-50 years range unlike the 5070 range in the present study. On the other hand, many recent studies reported consistent findings where more than $60 \%$ of the CKDu patients were over 50 years of age $[2,12]$ Spotty pigmentations on palms, observed by Paranagama [23] was consistent with similar type of patches observed in the patients of Thunukkai in the current study. Dermatological data of these patients who used arsenic rich water suggested the development of early stage of arsenic related keratosis. However, a proper histopathological investigation should be conducted for the validation purposes.

Drinking water quality parameters were compatible with the groundwater quality data available for North Central province through various $\mathrm{CKDu}$ based research conducted to date. However, the total hardness, calcium and magnesium ion concentration, electric conductivity levels of the groundwater of Thunukkai were substantially high compared to those of the groundwater of North Central province $[5,17,24,25]$. On the other hand, As and $\mathrm{Cd}$ in the groundwater of Thunukkai were low compared to the levels detected in the North Central province [5, 17]. Nevertheless, in agreement with the present study, Wickramarathna et al., [12] reported insignificant levels of $\mathrm{Cd}$ and As in groundwater of Girandurukotte, Wilgamuwa and Nikawewa areas. Chloride ion content in the groundwater of Thunukkai was 
high compared to the groundwater in CKDu high prevalent areas such as Padaviya, Kebithigollawa, Medawachchiya, \& Kahatagasdigiliya, and moderate prevalence areas such as Mihintale, Talawa, and Nochchiyagama of the dry zone of Sri Lanka [26]. Similarly, fluoride levels were relatively high in Thunukkai compared to those of the dry zone of Sri Lanka as reported by Chandrajith et al., [27]. Water hardness and the conductivity levels in Thunukkai were compatible with those of the high and moderately prevalent areas [26].

Correlation data of the water quality parameters and serum creatinine levels revealed a significant negative relationship with phosphate and positive relationships with total dissolved solid (TDS) and arsenic content of the drinking water. This observation was further confirmed by geospatial mapping of the quality of the constituents and the occurrence of higher serum creatinine levels in study samples. Patients with extremely high levels of serum creatinine (over $4.5 \mathrm{mg} / \mathrm{dL}$ ) appear to consume water from wells with higher TDS and arsenic contents. This higher availability of arsenic in ground water of Thenyiakulam (A9 site), Kalvilan (A12 site) Thunukkai (A4 site) may have related to the sediment characteristics of the area, where higher mobilization of arsenic ions occur through the availability of carbonate minerals of decaying organic matter which facilitate rapid release of arsenic ions from the As-adsorbed Feoxyanions in sediments $[28,29]$. Thus, in future studies, analysis of sediment characteristics of the drinking water sources may be pivotal for understanding the overall process.

Similar to arsenic, several other constituents in drinking water and the diet were linked with the serum creatinine levels [30]. For example, complying with the present study nitrate in the diet was only slightly linked with serum creatinine of $\mathrm{CKDu}$ patients $[31,32]$. In contrast to our results, significant association between the fluoride content and the occurrence of CKDu was revealed by several other researchers, including Illeperuma et.al., [7], Balasooriya et al., [9], Wickramarathna [12], Jayasinghe [33] and Wijeratne et.al., [34].

As given in the present study, phosphate ions in water may negatively influence the serum creatinine of CKDu patients. Thus, the negative sign of the coefficient implies that when phosphate content in the water increases, possibility of occurring CKDu decreases. The coefficient of phosphate shows that by holding nitrate, fluoride, total dissolved solid, total hardness and arsenic content, possibility to occur CKDu decreases by 0.2113 times for every unit increase in phosphate content. This result found to be consistent with Eddington et.al., [35]. Furthermore, total dissolved solids positively influence the serum creatinine levels of the study participants. The positive sign of the coefficient implies that when TDS content in the water increases, possibility to occur CKDu increases. The coefficient of TDS shows that by holding nitrate, fluoride, phosphate, total hardness and arsenic constant, possibility to occur CKDu increases by 0.2113 times for every unit increase in TDS content in water. On the other hand, total hardness showed no association with the serum creatinine levels, i.e. not compatible with Jayasumana et.al., [36] and Paranagama [37] who concluded positive and significant relationship between total hardness in water and CKDu. However, low $R^{2}$ value obtained in the present study may affect the significance of the findings. Thus, further studies should be conducted with a higher sample number and a broader study area.

\section{Conclusion}

The chronic kidney disease of unknown etiology in Thunukkai of the Mullaitivu District in the Northern Province of Sri Lanka showed male preponderance, M: F $4: 1$, at the age range of $50-70$, revealing $80 \%$ occupational association with agricultural activities. Secondary development of hypertension and diabetes were observed in CKDu patients. Spotty pigmentation, similar to arsenic related keratosis was observed in the palms of the patients, lived in the areas where detectable arsenic levels in their drinking water.

Evaluation of drinking water revealed substantially high ionic content leading to higher electric conductivity, salinity, total dissolved solids and total hardness levels compared to those of the Sri Lankan standards. Serum creatinine levels of the CKDu patients were significantly and negatively correlated with phosphate and positive correlation with arsenic and TDS contents, contributing more than $50 \%$ variation in serum creatinine. The results may be concluded that water quality parameters such as phosphate, total dissolved solid and arsenic content are significantly correlated with CKDu in Thunukkai of Mullaitivu District in Sri Lanka.

\section{Supplementary Information}

The online version contains supplementary material available at https://doi. org/10.1186/s12882-020-02157-1.

\section{Additional file 1.}

\section{Abbreviations}

COD: Chemical Oxygen Demand; CKDu: Chronic Kidney Disease of unknown etiology; EDTA: Ethylenediaminetetraacetic acid; GFAAS: Graphite furnace atomic absorption spectrophotometry; GIS: Geographic information system; GN: "Grama Niladhari"-Public service officer; NTU: Nephelometric Turbidity Unit; SD: Standard Deviation; SLS: Sri Lanka Standards; TDS: Total Dissolved Solids; WHO: World Health Organization

\section{Acknowledgements}

The authors wish to acknowledge Dr. K. Suseenthiran, medical officer Mallavi Hospital, Sri Lanka and medical officers from Provincial Director of Health Services, Northern Province. The study was supported by University Research Grant from University of Jaffna, Sri Lanka. 


\section{Authors' contributions}

KG carried out the study under the guidance of PS, UAJ, GR, RS and PJ. KG drafted the manuscript and UAJ and PJ reviewed it before the initial submission. All authors read and approved the final manuscript.

\section{Funding}

Financial support was provided by the University Research Grant from the University of Jaffna, Sri Lanka. The grant money was allocated for equipment, travel, consumables and miscellaneous and was spent over the course of research work. The funder, the University of Jaffna has no conflict of interest over publications produced though the study.

\section{Availability of data and materials}

The datasets used and/or analysed during the current study are available from the corresponding author on reasonable request. Additional data are available as a supplementary file.

\section{Ethics approval and consent to participate}

Ethical approval (Ref: J/ERC/17/82/NDR/0171) was granted from Ethics Review Committee (ERC) of Faulty of Medicine, University of Jaffna, Sri Lanka. Authors declare that the experiments conducted, complied with the current laws of Sri Lanka. Patient's data was collected through an interviewer administered questionnaire, filled during the visit to their houses. Verbal consent was taken as per the guidelines given by the ERC.

\section{Consent for publication}

Not applicable.

\section{Competing interests}

The authors declare that there is no conflict of interest.

\section{Author details}

${ }^{1}$ Centre for Environmental Studies and Sustainable Development, The Open University of Sri Lanka, Colombo, Sri Lanka. ${ }^{2}$ Industrial Technology Institute, 363, Bauddhaloka Mawatha, Colombo-7, Sri Lanka. ${ }^{3}$ Department of Zoology, Faculty of Natural Sciences, The Open University of Sri Lanka, Colombo, Sri Lanka. ${ }^{4}$ Department of Construction Technology, University College, Jaffna, Sri Lanka. ${ }^{5}$ Department of Surgery, Faculty of Medicine, University of Jaffna, Jaffna, Sri Lanka. ${ }^{6}$ Department of Chemistry, Faculty of Science, University of Jaffna, Jaffna, Sri Lanka.

Received: 19 February 2020 Accepted: 9 November 2020 Published online: 25 November 2020

\section{References}

1. Athuraliya TN, Abeysekera DT, Amerasinghe PH, Kumarasiri PV, Dissanayake $\checkmark$. Prevalence of chronic kidney disease in two tertiary care hospitals: high proportion of cases with uncertain aetiology. Ceylon Med J. 2009:54(1).2325.

2. Ranasinghe AV, Kumara GW, Karunarathna RH, De Silva AP, Sachintani KG, Gunawardena JM, Kumari SK, Sarjana MS, Chandraguptha JS, De Silva MV. The incidence, prevalence and trends of chronic kidney disease and chronic kidney disease of uncertain aetiology (CKDu) in the north Central Province of Sri Lanka: an analysis of 30,566 patients. BMC Nephrol. 2019;20(1):338.

3. Elledge MF, Redmon JH, Levine L, Wickremasinghe R, Waniyasuriya K, Joun R. Chronickidney disease of unknown etiology: quest for understanding and global publication: RTI Press Publication No. RB-0007-1405. Research Triangle Park; 2014.

4. Jayasekara KB, Dissanayake DM, Sivakanesan R, Ranasinghe A, Karunarathna $\mathrm{RH}$, Kumara GW. Epidemiology of chronic kidney disease, with special emphasis on chronic kidney disease of uncertain etiology, in the north central region of Sri Lanka. J Epidemiol. 2015;25(4):275-80.

5. Jayasumana C, Paranagama P, Agampodi S, Wijewardane C, Gunatilake S, Siribaddana S. Drinking well water and occupational exposure to herbicide is associated with chronic kidney disease - inPadavi- Sripura, Sri Lanka. Environ Health. 2015;14(6):6.

6. Jayatilake N, Mendis S, Maheepala P, Mehta FR. Chronic kidney disease of uncertain aetiology: prevalence and causative factors in a developing country. BMC Nephrol. 2013;14(1):180.

7. Illeperuma OA, Dharmagunawardhane HA, Herarh KPRP. Dissolution of aluminium from substandard utensils under high fluoride stress: A possible risk factors for chronic renal failure in the North-Central-Province. Natl Sci Found. 2009:37:219-22.

8. Nanayakkara S, Stmld S, Abeysekera T, Chandrajith R, Ratnatunga N, Edl G, Yan J, Hitomi T, Muso E, Komiya T, Harada KH. An integrative study of the genetic, social and environmental determinants of chronic kidney disease characterized by tubulointerstitial damages in the north central region of Sri Lanka. J Occup Health. 2014;56(1):28-38.

9. Balasooriya S, Munasinghe $H$, Herath AT, Diyabalanage S, lleperuma OA, Manthrithilake H, Daniel C, Amann K, Zwiener C, Barth JA, Chandrajith R. Possible links between groundwater geochemistry and chronic kidney disease of unknown etiology (CKDu): an investigation from the Ginnoruwa region in Sri Lanka. Exposure Health. 2019;17:1-2.

10. Koizumi A, Kobayashi H, Harada KH, Ratnatunga N, Parahitiyawa NB, Chandrajith R, Senevirathna STMLD, Nanayakkara S, Abeysekera T, Hitomi T. Whole-exome sequencing reveals genetic variants associated with chronic kidney disease characterized by tubulointerstitial damages in north central region, Sri Lanka. Environ Health Prev Med. 2015;20(5):354.

11. Sayanthooran S, Magana-Arachchi DN, Gunerathne L, Abeysekera T. Potential diagnostic biomarkers for chronic kidney disease of unknown etiology (CKDu) in Sri Lanka: a pilot study. BMC Nephrol. 2017;18(1):31.

12. Wickramarathna S, Balasooriya S, Diyabalanage S, Chandrajith R. Tracing environmental aetiological factors of chronic kidney diseases in the dry zone of Sri Lanka - a hydrogeochemical and isotope approach. J Trace Elem Med Biol. 2017;44:298-306.

13. Dissanayake CB, Chandrajith R. Fluoride and hardness in groundwater of tropical regions-review of recent evidence indicating tissue calcification and calcium phosphate nanoparticle formation in kidney tubules. Ceylon J Sci. 2019;48(3):197-207.

14. Dissanayake CB. Water quality in the dry zone of Sri Lanka-some interesting health aspects. J Natl Sci Found Sri Lanka. 2010;33(3):161-8.

15. WHO. Hardness in Drinking water, Document for Development of WHO Guidelines for Drinkingwater quality. The World Health Organization, Geneva, Switzerland; 2011.

16. Wasana HM, Aluthpatabendi D, Kularatne WM, Wijekoon P, Weerasooriya R, Bandara J. Drinking water quality and chronic kidney disease of unknown etiology (CKDu): synergic effects of fluoride, cadmium and hardness of water. Environ Geochem Health. 2016;38(1):157-68.

17. Jayasumana C, Paranagama PA, Amarasinghe MD, Wijewardane KMRC, Dahanayake KS, Fonseka SI, Rajakaruna KDLMP, Mahamithawa AMP, Senanayake VK SUD. Possible link of chronic arsenic toxicity with chronic kidney disease of unknown etiology in Sri Lanka. J Nat Sci Res. 2013;3(1):64-73.

18. Dissanayake DM, Jayasekera JM, Ratnayake $P$, Wickramasinghe $P$, Radella YA, Shihana F. Short term effects of crude extracts of cyanobactria blooms of reservoirs in high prevalence area for CKD in Sri Lanka on mice. In:kidney proceeding. Sri Lanka: University of Peradeniya; 2011.

19. WHO \& NSF. Designing a step wise approach to estimate the burden and to understand the etiology of CKDu in Sri Lanka. In: Workshop report. Sri Lanka; 2016.

20. Kafle K, Balasubramanya S, Horbulyk T. Prevalence of chronic kidney disease in Sri Lanka: a profile of affected districts reliant on groundwater. Sci Total Environ. 2019 Dec 1;694:133767.

21. Wanigasuriya KP, Peiris H, Heperuma N, Peiris RB, Wickremasinghe R. Could ochratoxinin food commodities be the cause of chronic kidney disease in Sri Lanka? Tranesactions R Soc Trop Med Hyg. 2008;102:726-8.

22. Noble A, Amerasinghe $P$, Manthrithilake $H$, Arasalingam S. Review of literature on chronic kidney disease of unknown etiology (CKDu) in Sri Lanka: IWMI, International Water Management Institute, Battaramulla, Sri Lanka; 2014.

23. Paranagama PA. Potential link between ground water hardness, arsenic content and prevalence of CKDu. InProceedings of the Symposium on "Chronic kidney disease of uncertain origin (CKDu): A scientific basis for future action; 2013. p. 1-8.

24. Wasana HMS, Perera GDRK, Gunawardena PSD, Bandara J. The impact of aluminum,fluoride, and aluminum-fluoride complexes in drinking water on chronic kidney disease. Environ Sci Pollut Res. 2015;22(14):11001-9.

25. Aqeelah Faleel $R$, Jayawardena U. Is it safe to drink water in Mihintale?; A case study from disease endemic areas of the Chronic Kidney Disease of unknown aetiology (CKDu). In: 17th Annual Research Sessions of the Open University of Sri Lanka; 2019.

26. Cooray T, Wei Y, Zhong H, Zheng L, Weragoda SK, Weerasooriya AR. Assessment of groundwaterquality in CKDuaffectedareas of Sri Lanka: 
implications for drinkingwatertreatment. Int J Environ Res Public Health. 2019;16(10):1698.

27. Chandrajith R, Diyabalanage S, Dissanayake CB. Geogenic fluoride and arsenic in groundwater of Sri Lanka and its implications to community health. Groundw Sustain Dev. 2020;10:100359.

28. Bandara UG, Diyabalanage S, Hanke C, van Geldern R, Barth JA, Chandrajith R. Arsenic-rich shallow groundwater in sandy aquifer systems buffered by rising carbonate waters: a geochemical case study from Mannar Island, Sri Lanka. Sci Total Environ. 2018;633:1352-9.

29. Amarathunga U, Diyabalanage S, Bandara UG, Chandrajith R. Environmental factors controlling arsenic mobilization from sandy shallow coastal aquifer sediments in the Mannar Island, Sri Lanka. Appl Geochem. 2019 Jan 1;100:152-9.

30. Siriwardhana ER, Perera PA, Sivakanesan R, Abeysekara T, Nugegoda DB, Weerakoon KG. Is the staple diet eaten in Medawachchiya, Sri Lanka, a predisposing factor in the development of chronic kidney disease of unknown etiology?-a comparison based on urinary $\beta$ 2-microglobulin measurements. BMC Nephrol. 2014;15(1):103.

31. Mirmiran P, Bahadoran Z, Golzarand M, Asghari G, Azizi F. Consumption of nitrate containing vegetables and the risk of chronic kidney disease: Tehran lipid and glucose study. Ren Fail. 2016;38(6):937-44.

32. Silva CS. Water quality assessment in Jaffna, Vavuniya, Anuradhapura, Kurunagala and Hambantota in Sri Lanka for domestic purposes. Proceedings of the Annual Academic Sessions of the Open University of Sri Lanka; 2010.

33. Jayasinghe YK. CHRONIC KIDNEY DISEASE. Risk factor identification. Secondary data analysis. In: IWMI reports; 2011.

34. Wijerathne C, Weragoda SK, Kawakami T. A reviewof Chronic Kidney Disease Due to Unknown Etiology and Groundwater Quality in Dryzone, Sri Lanka. In: International Conference on Advances in Advances in Applied Science and Environmental Engineering (ASEE), Malaysia, Organized by Institute of Research Engineers and Doctors, USA; 2014.

35. Eddington H, Hoefield R, Sinha S, Chrysochou C, Lane B, Foley RN, Hegarty J, New J, O'Donoghue DJ, Middleton RJ, Kalra PA. Serum phosphate and mortality in patient with chronic kidney disease. Clin J Am Soc Nephrol. 2010;5(12):2251-7.

36. Jayasumana C, Gunatilake S, Senanayake P. Glyphosate, hardwater and nephrotoxic metals:are they the culprits behind the epidemic of chronic kidney disease of unknown etiology in Sri Lanka?Int J environ res. Public Health. 2014;11(2):2125-47.

37. Parangama A, Jayasuriya N, Bhuiyan MA. Water quality parameters in relation to ChronicKidney Disease in Sri Lanka. In: Jayasinghe, Mendis, Fernando S, Janaka Y, Ranjith Dissanayake R, editors. Capacity Building for Sustainability MTR. Kandy: University of Peradeniya; 2013. p. 173-83.

\section{Publisher's Note}

Springer Nature remains neutral with regard to jurisdictional claims in published maps and institutional affiliations.

\section{Ready to submit your research? Choose BMC and benefit from:}

- fast, convenient online submission

- thorough peer review by experienced researchers in your field

- rapid publication on acceptance

- support for research data, including large and complex data types

- gold Open Access which fosters wider collaboration and increased citations

- maximum visibility for your research: over $100 \mathrm{M}$ website views per year

At BMC, research is always in progress.

Learn more biomedcentral.com/submissions 